reduced by decrements of $2 \mathrm{mg}$. every two days, and she was stabilized on a dosage of $8 \mathrm{mg}$. daily $(2 \mathrm{mg}$. four times daily).

Improvement in the rheumatoid arthritis was dramatic. She now managed her ordinary housework comfortably and for the first time in many years she was able to walk outside. The improvement continued and she was seen at 3-4-day intervals.

Five weeks after commencing treatment she noticed an increase in weight and a change in facial appearance. Examination disclosed a typical "moon-shaped " face with pitting oedema of forehead (see Fig.). The blood pressure at the start of treatment was $130 / 80$, but this was now raised to $160 / 100$. There was also oedema of arms and legs and she showed moderate euphoria. The serum sodium, potassium, and chloride, and the results of an oral glucose tolerance test, were within normal limits. The dosage of triamcinolone was gradually reduced to $4 \mathrm{mg}$. daily, which did not completely relieve the symptoms of her rheumatoid arthritis compared with the former level of $8 \mathrm{mg}$. daily. The "moon face" has diminished but has not entirely regressed even after four weeks on this reduced dosage. The oedema of arms and legs completely disappeared, but some euphoria remains.

This case shows that even with a low dosage of triamcinolone cushingoid features may develop. Hart ${ }^{3}$ has shown that triamcinolone also exacerbates peptic ulcer symptoms. Caution is therefore urged in the use of this steroid.-We are, etc.,

I. MCLEAN BAIRD.

Barnsley, Yorks.

$$
\text { N. M. Piercy. }
$$

REFERENCES

${ }^{1}$ Freyberg, R. H., Berntsen, C. A., Hellman, L., and Gallagher, T. F., Proceedings of the 9 th International Congress on Rheumatic Diseases, 1957, p. 79.

- Freyberg, R. H., Berntsen, C. A., and Hellman, L., Arthr. and Rheum., 1958, 1, 215.

s Hart, F. D., Golding, J. R., and Burley, D., Lancet, 1958, 2 , 495 .

\section{Skin Disinfection}

SiR,-We read your annotation (Journal, May 30, p. 1398) on skin disinfection with interest. We have been testing disinfectants and obtained the following results :

Solutions of " hibitane" (chlorhexidine diacetate) $0.5 \%$ $(1 / 200)$ in $70 \%$ spirit, hibitane $0.5 \%(1 / 200)$ and $10 \%$ formaldehyde in $70 \%$ spirit, "iodevan" (conc.) and a 1/10 dilution of iodevan were tested against a series of organisms. Resistant strains of Staphylococcus aureus (coagulase positive), an aerobic spore bearer, Pseudomonas pyocyanea, a coliform bacillus, proteus, and Clostridium tetani were chosen (resistant to $1 / 80$ phenol at 5 minutes and 1/90 phenol at 15 minutes). They were incubated in broth at $37^{\circ} \mathrm{C}$. for three successive days before use.

Screening tests were done by inoculating $50 \mathrm{ml}$. sterile broth, first with a loopful of antiseptic and then with the test organism and incubating for $\mathbf{4 8}$ hours. No growth indicated a carry-over reaction of the antiseptic inhibiting growth. It was found that with Staphylococcus aureus and an aerobic spore bearer, using hibitane $0.5 \%(1 / 200)$ in $70 \%$ spirit and hibitane $0.5 \%(1 / 200)$ and $10 \%$ formaldehyde in $70 \%$ spirit, a carry-over reaction was present, and thus in these two instances the concentration of hibitane used was $0.05 \%$ $(1 / 2,000)$

Five ml. antiseptic and $0.5 \mathrm{ml}$. test organisms were thoroughly mixed by shaking. With a standard loop and at fixed times (see Table) $50 \mathrm{ml}$. of sterile broth was inoculated. Controls were also set up and both incubated for 48 hours at $37^{\circ} \mathrm{C}$. The bottles in which no growth occurred were reinoculated with the test organisms to recheck for any carry-over reaction of the antiseptic.

It was found that hibitane in spirit and hibitane with formaldehyde in spirit gave the same results except in the case of the spore bearers, where the latter was more

\begin{tabular}{|c|c|c|c|c|c|c|c|}
\hline & $30 \mathrm{sec}$. & $1 \mathrm{~min}$. & $2 \mathrm{~min}$. & $3 \mathrm{~min}$. & $8 \mathrm{hr}$. & $17 \mathrm{hr}$. & $24 \mathrm{hr}$. \\
\hline 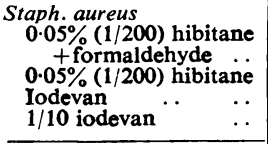 & $\begin{array}{l}+ \\
+ \\
+ \\
+\end{array}$ & $\begin{array}{l}\overline{+} \\
+ \\
+\end{array}$ & 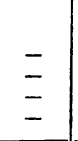 & $\bar{z}$ & & & \\
\hline $\begin{array}{c}\text { Aerobic spore bearer } \\
0.05 \%(1 / 2,000) \\
\text { tane hibi- } \\
0.05 \%(1 / 200) \text { hibitane } \\
\text { Iodevan } \quad \ldots \quad \ldots \\
\begin{array}{ll}1 / 10 \text { iodevan } & \ldots\end{array}\end{array}$ & $\begin{array}{l}+ \\
+ \\
+ \\
+\end{array}$ & $\begin{array}{l}+ \\
+ \\
+ \\
+\end{array}$ & $\begin{array}{l}+ \\
+ \\
+ \\
+\end{array}$ & $\begin{array}{l}+ \\
+ \\
+ \\
+\end{array}$ & $\begin{array}{l}+ \\
+ \\
+ \\
+\end{array}$ & $\underline{+}$ & + \\
\hline 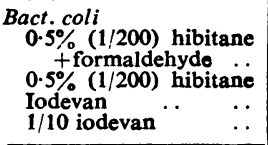 & $\begin{array}{l}- \\
\overline{+} \\
+\end{array}$ & $\begin{array}{l}\overline{+} \\
+ \\
+\end{array}$ & $\bar{z}$ & $\vec{z}$ & & & \\
\hline 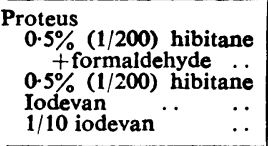 & $\begin{array}{l}\overline{-} \\
+ \\
+\end{array}$ & $\begin{array}{l}\overline{+} \\
\overline{+}\end{array}$ & $\begin{array}{l}\overline{-} \\
\overline{-}\end{array}$ & $\vec{I}$ & & & \\
\hline 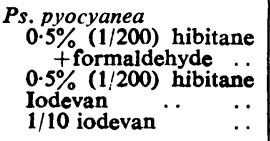 & $\begin{array}{l}- \\
+ \\
+\end{array}$ & $\frac{-}{+}$ & $\begin{array}{l}\overline{-} \\
- \\
-\end{array}$ & $\begin{array}{l}\bar{I} \\
\overline{-}\end{array}$ & & & \\
\hline 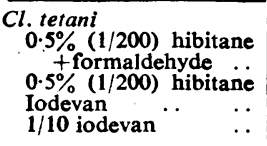 & $\begin{array}{l}+ \\
+ \\
+ \\
+\end{array}$ & $\begin{array}{l}+ \\
+ \\
+ \\
+\end{array}$ & $\begin{array}{l}+ \\
+ \\
+ \\
+\end{array}$ & $\begin{array}{l}+ \\
+ \\
+ \\
+\end{array}$ & $\begin{array}{l}+ \\
+ \\
+ \\
+\end{array}$ & $\vec{t}$ & + \\
\hline
\end{tabular}

$+=$ Growth. $-=$ No growth.

efficient. Also the iodevan (conc.) and a 1/10 dilution of iodevan gave the same results. Keeping the hibitane and formaldehyde solution for one month had no effect on its antiseptic properties.-We are, etc.,

The General Hospital,

Birmingham, 4 .

SIR,-Without in any way suggesting that the careful preparation of the skin before injection is not necessary in hospital, it may be of interest to record that during 37 years in general practice I never prepared the skin in any way whatever (except when, very rarely, I wished to impress the patient), and never had any trouble. Furthermore, I only sterilized the syringe by rinsing it out repeatedly with boiling or near-boiling water. The doctor I joined, 20 years my senior, did not even go so far as that, but only rinsed out the syringe successively in two cups of hot water. He did have one septic arm in the $4 \frac{1}{2}$ years I was with him.

It is impossible to believe that he and I were just lucky over so many years. Surely the answer is that patients develop an immunity to their own bacterial flora, and in general practice ordinary care and cleanliness on the part of doctor and nurse is enough to avoid the chance of introducing foreign bacteria to which the patient has little or no immunity. It is obvious, of course, that the results would be very different if the doctor were a carrier of virulent bacteria, but would such an unfortunate individual be suitable for general practice even with the most stringent precautions ?-I am, etc.,

Bracknell, Berks.

L. G. JACOB. 